DOI 10.20873/uft.2359-0106.2021.v8n2.p293-323

\title{
OS LIMITES DO SUPREMO TRIBUNAL FEDERAL COMO LEGISLADOR NEGATIVO
}

\section{THE LIMITS OF THE FEDERAL SUPREME COURT AS NEGATIVE LEGISLATOR}

Elenice Rolemberg Santos ${ }^{1}$
Necessio Adriano Santos

\section{RESUMO}

O presente artigo tem como objetivo analisar as limitações impostas ao Supremo Tribunal Federal (STF) em decorrência do princípio da separação dos poderes. Além disso, buscou demonstrar a possibilidade da existência de um novo poder para que, consequentemente, a teoria tripartite pudesse ser alterada ou, até mesmo, abolida. Neste sentido, não deve o STF ter suas atribuições limitadas por um princípio, sendo ele possibilitado de inovar e criar o Direito. Contudo, nota-se a impossibilidade do fim da teoria, visto que foi estabelecida pela Constituição Federal de 1988 como uma cláusula pétrea, isto é, inalterável, não ficando a cargo do STF inovar ou contestar o que por ela foi estabelecido, sob pena de inconstitucionalidade da decisão. Por fim, para a presente pesquisa, o método utilizado foi o exploratório, baseando-se em livros e dissertações sobre o assunto. Ademais, o trabalho teve como principal motivação a possibilidade de responder se existe ou não um quarto poder e quais os impactos dessa possibilidade para o STF, questionamento realizado em sala no início da academia de Direito.

1 Graduanda em Direito pela Faculdade de Administração e Negócios de Sergipe; Graduanda em Espanhol pela Universidade Federal do Ceará; Bolsista de iniciação científica no Instituto Brasileiro de Ciências Criminais; Intercambista na Faculdade de Direito da Universidade de Buenos Aires. Email: elenicersantos07@gmail.com Orcid: https://orcid.org/0000-0003-2860-8678 Endereço de contato:

Travessa b1, 49, Piabeta, Nossa senhora do socorro/SE

2 Possui graduação em Direito pela Universidade Federal de Sergipe (2015), graduação em Ciências Contábeis pela Universidade Federal de Sergipe (2009), graduando em Ciências Sociais pela UFS, mestrado em Desenvolvimento e Meio Ambiente pela Universidade Federal da Paraíba (2017), especialização em Direito Constitucional pela FAIARA (2016) e especialização em Direito Penal pela FAIARA (2016), pós-graduando em Tutoria em Educação a Distância e Docência do Ensino Superior pela Faculdade Futura. Especialização em Gestão das Organizações Públicas pela UFS. Atualmente é Professor do Curso de Direito da FANESE. E-MAIL: necessio@gmail.com ORCID https://orcid.org/00000002-0607-0064 ENDEREÇO DE CONTATO Av. José Conrado de Araújo, 320, Cond. Vila Poesia, Bloco 5, Ap 6, Bairro Industrial, Aracaju/Se 
DOI 10.20873/uft.2359-0106.2021.v8n2.p293-323

PALAVRAS-CHAVE: Amarras impostas ao STF. Fim da Tripartição dos poderes. Ministério Público e sua nova atribuição Tripartição dos poderes.

\section{ABSTRACT}

This article aims to analyze the limitations imposed on the Supreme Federal Court as a result of the principle of separation of powers. In addition, it sought to demonstrate the possibility of the existence of a new power so that, consequently, the tripartite theory could be altered or even abolished. In this sense, the Supreme Court should not have its powers limited by a principle, since it is possible to innovate and create the Law. However, the impossibility of ending the theory is noted, since it was established by the Federal Constitution of 1988 as a stone clause, that is, unalterable, and it is not the responsibility of the Supreme Federal Court to innovate or contest what was established by it, under penalty of unconstitutionality of the decision. Finally, for this research, the method used was exploratory, based on books and dissertations on the subject. Furthermore, the main motivation for this work was the possibility of answering whether or not there is a fourth power and what are the impacts of this possibility for the STF, a question asked in the classroom at the beginning of the Law Academy.

KEYWORDS: End of Tripartition of Powers. Public Ministry and its new assignment. Strings imposed on the STF. Tripartition of powers.

\section{INTRODUÇÃO}

O propósito da presente pesquisa é compreender o que é e quais as funções da Teoria da Tripartição dos poderes revelando qual sua importância para a estruturação do ordenamento jurídico brasileiro através do estudo de como foi alicerçada no texto constitucional através do princípio da separação dos poderes. Uma das bases do constitucionalismo encontra-se fundamentada no referido princípio e também dos freios e contrapesos que garantem a independência e harmonia entre os poderes Legislativo, Executivo e Judiciário, possibilitando o equilíbrio e controle mútuo do poder pelo próprio poder, fruto da luta da sociedade contra a concentração de poder (PALMA, 2011).

O estudo busca compreender como se configura o princípio da separação dos poderes no ordenamento jurídico brasileiro, e especialmente no que tange a atuação do Supremo Tribunal Federal (STF), órgão integrante do poder judiciário, analisar os seus 
limites como legislador positivo. Além de verificar se as funções do Ministério Público (MP) estariam deslocadas dentro dessa tradicional teoria tripartite de poderes, dando assim origem a um quarto poder.

Objetiva-se com a presente pesquisa questionar se o STF não deveria ter suas funções resumidas à proteção da Constituição Federal e às declarações das normas inconstitucionais, ou deve agir em prol de uma atuação mais satisfatória, isto é, uma atuação ativa? Para que isso seja possível, defende-se que a teoria tripartite terá que ser alterada ou abolida, tendo como fundamento a inclusão do Ministério Público como um novo poder e, diante isto, o STF conseguirá exercer suas funções de maneira plena e satisfatória.

Para fundamentar a pesquisa, a metodologia utilizada será a exploratória, visto que será desenvolvida a partir de livros e dissertações acerca do assunto. $O$ interesse pelo assunto foi demonstrado no início da academia, através de uma aula de Direito Constitucional onde nos foi questionado se seria possível a existência de um quarto poder e quais seriam as consequências atribuídas aos demais poderes. Desde então, esse questionamento me intrigou e me despertou para a produção cientifica.

O presente trabalho será dividido em 4 seções para demonstrar com maior facilidade os impactos da possibilidade da existência de um novo poder, bem como a sua repercussão para o STF e, desta maneira, facilitar o entendimento do texto.

A primeira seção busca apresentar a teoria tripartite e sua evolução. Neste contexto, faz-se necessário demonstrar a sua importância para o ordenamento jurídico, abrangendo ainda ao sistema de freios e contrapesos e o porquê de sua permanência da separação na CF de 1988, visto que se tornou um princípio constitucional.

A segunda seção trata da evolução do Supremo Tribunal, das suas funções e limitações em decorrência do princípio da separação dos poderes. Além disso, se debruça sobre algumas das sentenças do STF para verificar se está atuando dentro dos limites estabelecidos pela Constituição e em observância aos princípios constitucionais, em especial ao princípio da separação dos poderes. 
A terceira seção se debruça sobre o Ministério Público como um quarto poder, analisando suas funções estabelecidas através do rol taxativo da CF de 1988. Ademais, analisa a possibilidade de uma suposta usurpação de poder por parte do MP, visto que a função típica de investigar, hipoteticamente, é de competência da polícia judiciária.

Por fim, a quarta seção procura analisar a (im)possibilidade do fim da teoria tripartite, visto que, ao falar do fim da tripartição, o MP poderia ser considerado um novo poder, sendo o STF livre para inovar e criar o Direito através do poder de legislar, não se limitando a apenas o fazer em situações específicas.

\section{SEPARAÇÃO DE PODERES E A TEORIA TRIPARTITE}

Cada indivíduo é uma unidade personificada de normas e detentor de direitos políticos, sendo também um propulsor para a continuação da existência do estado político, visto que é um sujeito jurídico dotado de direitos e deveres (KELSEN, 1999). O Estado político é a união de toda as forças particulares, forças essas advindas da sociedade, isto é, não há que se falar em estado político sem uma sociedade que o constrói uma vez que as leis decorrem da realidade coletiva e histórica de um povo (MONTESQUIEU, 2000).

A fim de criar uma limitação, moderação e racionalização dos poderes do Estado político, a Carta magna de 1988 estabeleceu o princípio da separação de poderes em seus dispositivos como uma cláusula pétrea (BARROSO, 2019). Neste sentido, este princípio, não pode ser emendado e nem abolido e está elencado na CF de 1988, onde encontra-se disposto no artigo 60 , parágrafo $4^{\circ}$ :

Art. 60. A Constituição poderá ser emendada mediante proposta:

$\S 4^{\circ}$ Não será objeto de deliberação a proposta de emenda tendente a abolir:

I - a forma federativa de Estado;

II - o voto direto, secreto, universal e periódico;

III - a separação dos Poderes;

IV - os direitos e garantias individuais (BRASIL, 1988). 
Destarte, o Estado é formado por três poderes fundamentais para que, desse modo, consiga se adaptar às mudanças estabelecidas pela constituinte. Sendo assim, os três poderes passaram a interpretar a Constituição, baseando-se nos princípios fundamentais nela dispostos, sendo necessária a harmonia entre os poderes com a intenção de fazer com que o governo funcione de maneira harmônica, tendo como finalidade o bom trabalho em benefício da sociedade (BARROSO, 2019).

Para tanto, o primeiro poder fundamental diz respeito à função de elaborar e suprimir as leis, decretar a pena de morte, de banimento e de confisco, assim como prestar contas aos magistrados, poder este denominado por Aristóteles como deliberação (ARISTÓTELES, 1991). A deliberação não foi adotada fielmente pela Constituição Federal, visto que o poder antes denominado de deliberação agora é chamado de poder Legislativo, e é exercido pelo Congresso, em sistema bicameral, compreendendo a Câmara dos Representantes e o Senado (BARROSO, 2019).

O segundo poder é o poder Executivo, o qual é exercido por magistrados, que são escolhidos de formas diferentes em cada Estado, visto que, o requisito para esse cargo é fazer parte do poder público. Diante disso, pode-se observar que a vontade do coletivo é essencial para a composição desse poder, visto que, para que um novo magistrado seja colocado no poder se faz necessária uma eleição que é realizada através de Assembleia Geral composta pela população ou, em alguns casos, através de sorteio (ARISTÓTELES, 1991).

O poder Judiciário é o terceiro, que atribui ao magistrado a competência de punir e julgar crimes da ordem civil (MONTESQUIEU, 2000). O poder Judiciário possui poder sobre a liberdade das pessoas, isto é, ele pode cessar a liberdade de quem comete um crime. Reservar o poder de legislar ao poder do Judiciário e entregá-lo à uma única pessoa, faz com que ela tenha um domínio sobre a vida particular e a vida política do cidadão, tendo em vista que o poder de legislar é quem dita as regras para criar ou não uma nova lei (BONAVIDES, 2016).

Com o intuito de que os poderes sejam funcionais, the são atribuídas competências privativas e, para tanto, existem três requisitos que devem ser 
analisados: (i) os poderes devem ser exercidos por pessoas distintas, isto é, não pode a mesma pessoa fazer parte de dois poderes simultaneamente; (ii) nenhum membro dos poderes pode ser excluído por questões políticas; e (iii) cada poder é independente, contudo, são atribuídas funções típicas (predomínio daquela função) e outras funções (chamadas normalmente de atípicas), como reforço de sua independência frente aos demais poderes (BARROSO, 2019).

\subsection{Sistema de freios e contrapesos}

A lei maior da Inglaterra contemplava os três poderes, sendo eles: o poder Legislativo, o Executivo das coisas que emendem o direito das gentes e o Executivo daquelas que dependem do direito civil. Em sua Constituição, cada poder deveria respeitar as funções delimitadas para cada um. Já a Carta Magna Brasileira, não adotou a mesma separação feita pela Constituição da Inglaterra, visto que é dividida em poder Legislativo, Executivo e Judiciário (MONTESQUIEU, 2000).

Além disso, Montesquieu desenvolveu um sistema denominado de sistema de freios e contrapesos, também conhecido como princípio da separação dos poderes, o qual possuiu como fundamento seus estudos e a construção teórica já existente. A separação versava sobre não deixar os poderes nas mãos de uma única pessoa e transferi-los entre órgãos para que assim, os direitos individuais fossem assegurados (BARROSO, 2019).

Os freios e contrapesos além de determinar a separação das funções de cada poder, criou formas que permitem a correlação entre eles (CAMARGO, 2017). O sistema surgiu para limitar que os poderes fossem dados a uma única pessoa. Com isto, surge um Estado democrático, liberal e social, no qual a sociedade adquire direitos e deveres (COSTA, 2014).

Ademais, o sistema de freios e contrapesos criou mecanismos para conter os abusos de poder, sendo essa uma possibilidade de respeitar os direitos individuais. Destarte, com o intuito de que os poderes convivam em harmonia, existem limitações das funções designadas e os poderes devem respeitá-las para que um não justaponha 
o outro (CAMARGO, 2017). Diante disso, podemos analisar que o princípio da separação dos poderes limita, organiza e dispõe da harmonia necessária para que os poderes funcionem em prol do bem da população (COSTA, 2014).

\subsection{A separação de poderes como princípio constitucional}

O princípio da separação dos poderes surgiu com a finalidade de estruturar e organizar o Estado constitucional e transformou-se em uma ratio essendi da lei suprema. A separação dos poderes significa a independência do Estado da soberania e pode ser classificada em horizontal ou vertical, sendo a horizontal referente a separação de órgãos e funções, enquanto a vertical faz referência a delimitação das competências. A separação horizontal faz menção à diferenciação funcional, isto é, legislação, execução e jurisdição, enquanto a vertical visa delimitar as competências a que os órgãos se relacionam reciprocamente (CANOTILHO, 2003).

A ideia de separação dos poderes existe desde os tempos de Aristóteles, visto que o filósofo já discutia essa questão quando escrevia que todo governo possui três poderes essenciais e que cada legislador deve observar o poder designado como seu de forma coesa, sendo a harmonia entre eles um propulsor para que o governo funcione em prol do interesse público e do bem estar da sociedade. O filósofo entendia que o governo era dividido em poder Deliberativo, Executivo e Judiciário (BARBOSA, 2016).

Segundo Montesquieu, os poderes seriam separados em Executivo, Legislativo e Judiciário, entretanto, mesmo com a separação, se fazia necessário que o monarca desse a palavra final para as decisões tomadas pelos poderes. Para Montesquieu, o indivíduo só teria sua liberdade garantida se os poderes fossem separados e, consequentemente, retirados das mãos de uma única pessoa. De acordo com Montesquieu a separação dos poderes é uma forma de impossibilitar a criação de leis tirânicas (BADAWI, 2014).

Em 1787, a Carta Magna americana contemplou a separação dos poderes, isto é, o poder foi repartido. Os poderes Executivo e Legislativo possuíram normas mais 
rígidas, visto que a república era presidencialista, fato que gerou como consequência o afastamento do parlamento, já que era vinculado a monarquia. A figura do monarca foi trocada pelo Presidente da República eleito pelos cidadãos. A lei suprema Americana inspirou diversos países, dentre eles, o Brasil (NASCIMENTO, 2017).

Ademais, a Declaração Universal dos Direitos Humanos de 1798 estabeleceu em seu artigo 16 que o Estado teria que contemplar o princípio da separação dos poderes para que dessa forma pudesse ter uma Constituição em vigor, visto que tal princípio serve de limitador dos poderes do Estado. A Declaração de 1798 destacou também a ligação dos direitos fundamentais com o princípio, isto é, para que os direitos fundamentais sejam respeitados, o princípio da separação dos poderes deve ser observado (FERNANDES, 2011).

O princípio da separação dos poderes é uma medida para limitar os poderes do Estado, assegurando assim, uma medida jurídica ao poder e uma forma de garantir e proteger os direitos dos indivíduos. A limitação, divisão e o controle do poder podem ser analisados como uma dimensão negativa e, em contrapartida, a separação como constitucionalização, ordenação e organização do poder é vista como satisfatória e eficaz, sendo considerada uma dimensão positiva. Diante disso, a separação tende a ser a responsabilidade diante da execução de um poder (CANOTILHO, 2003).

\section{EVOLUÇÃO DO SUPREMO TRIBUNAL FEDERAL NO ORDENAMENTO JURÍDICO BRASILEIRO}

Nos Estados Unidos, o princípio da separação dos poderes é considerado um dogma, sendo responsabilidade do juiz estabelecer o equilíbrio constitucional e por dizer o Direito, não observando os princípios basilares e sim, buscando a solução do conflito. Os Estados Unidos serviram de inspiração para a criação do Tribunal no Brasil, sendo ele responsável por dizer o Direito, mas, deve ele observar os princípios e dessa forma, racionalizar a justiça constitucional (STRECK, 2018).

O Supremo Tribunal Federal foi o órgão criado para ser responsável por dizer o Direito e vem se fortalecendo ao longo do tempo, se tornando uma instituição 
indispensável para assegurar a garantia dos direitos fundamentais da população brasileira. Contudo, as coisas nem sempre foram assim, para que o STF chegasse ao nível de importância atual, passou por diversas alterações, como iremos analisar a seguir diante dos estudos históricos acerca da evolução do STF nas constituições brasileiras (BRASIL, 2020c).

Quadro 01 - Evolução histórica do Supremo Tribunal Federal nas Constituições brasileiras

\begin{tabular}{|l|l|}
\hline CONSTITUIÇÃO & EVENTO \\
\hline Constituição do do & $\begin{array}{l}\text { Com a proclamação da independência do Brasil, a } \\
\text { Impensio de 1824 } \\
\text { Justiça e trouxe esboços de uma suposta limitação dos } \\
\text { poderes através de um equilíbrio e, para tanto, estabeleceu } \\
\text { que ao Supremo Tribunal incumbia as funções de conceder } \\
\text { ou delegar as revistas dos casos, conhecer e analisar os } \\
\text { erros de ofício, conhecer e decidir sobre os conflitos de } \\
\text { jurisdição, além das Relações Provinciais. Diante disso, } \\
\text { pode-se observar que o poder Judiciário foi transformado } \\
\text { num órgão dotado de autonomia. }\end{array}$ \\
\hline $\begin{array}{l}\text { Governo Provisório } \\
\text { de 1890 }\end{array}$ & $\begin{array}{l}\text { O poder Judiciário sofreu algumas alterações, dentre elas a } \\
\text { nomenclatura do Supremo Tribunal da Justiça que passou a } \\
\text { ser denominado de Supremo Tribunal Federal e estabeleceu } \\
\text { que em sua composição estariam quinze juízes } \\
\text { selecionados dentre os trinta juízes federais mais antigos e } \\
\text { cidadãos de notável saber e reputação elegíveis para o } \\
\text { Senado. }\end{array}$ \\
\hline Decreto no 510, de de \\
1890 & $\begin{array}{l}\text { As funções do Supremo Tribunal Federal foram alteradas } \\
\text { pelo decreto, visto que ao STF passou a incumbir as } \\
\text { funções de privativamente processar e julgar: o Presidente } \\
\text { da República nos crimes comuns, e os Ministros de Estado, } \\
\text { os ministros diplomáticos, nos crimes comuns e nos de } \\
\text { responsabilidade; os pleitos entre a União e os estados, ou } \\
\text { entre estes uns com os outros; os litígios e reclamações } \\
\text { entre nações estrangeiras e a União, ou os estados; os } \\
\text { conflitos dos juízes ou tribunais federais entre si, ou entre } \\
\text { esses e os dos estados. Também foi estabelecida como }\end{array}$ \\
\hline
\end{tabular}




\begin{tabular}{|c|c|}
\hline & $\begin{array}{l}\text { função do STF julgar, em grau de recurso, as questões } \\
\text { resolvidas pelos juízes e tribunais federais e rever os } \\
\text { processos findos. }\end{array}$ \\
\hline $\begin{array}{l}\text { Texto Republicano } \\
\text { de } 1891\end{array}$ & $\begin{array}{l}\text { Estabeleceu a forma de governo sob o regime } \\
\text { representativo e dedicou ao Supremo Tribunal Federal } \\
\text { alguns artigos. Ademais, foi adicionada privativamente a } \\
\text { competência do STF, através da constituinte, requisitar do } \\
\text { Poder Executivo a intervenção nos estados, a fim de } \\
\text { assegurar a execução das sentenças federais. }\end{array}$ \\
\hline $\begin{array}{l}\text { Decreto } 19.653 \text { de } \\
\text { fevereiro de } 1931 \\
\text { e Constituição da } \\
\text { República de } 1934\end{array}$ & $\begin{array}{l}\text { Fez uma alteração importante na composição do Supremo } \\
\text { Tribunal Federal com a redução de sua composição para } \\
\text { onze juízes, sendo esta mantida pela Constituição de } 1934 \text {. } \\
\text { Entretanto, o STF passou a ser chamado de Corte Suprema } \\
\text { e os juízes substituídos por ministros, podendo a Corte } \\
\text { Suprema ser dividida em Câmaras e Turmas. }\end{array}$ \\
\hline $\begin{array}{l}\text { Carta Magna de } \\
1937\end{array}$ & $\begin{array}{l}\text { Modificou a denominação de Corte Suprema restabelecendo } \\
\text { a denominação de Supremo Tribunal Federal, continuou } \\
\text { com a mesma composição e competências. Depois de ter } \\
\text { funcionado no Rio de Janeiro por } 69 \text { anos, em } 21 \text { de abril de } \\
1960 \text {, em decorrência da mudança da capital federal, o } \\
\text { Supremo Tribunal Federal transferiu-se para Brasília e ficou } \\
\text { sediado na Praça dos Três Poderes. }\end{array}$ \\
\hline $\begin{array}{l}\text { Ato Institucional de } \\
1965,1967 \text { e } \\
1969\end{array}$ & $\begin{array}{l}\text { O ato institucional entrou em vigência e estabeleceu que a } \\
\text { composição do Supremo Tribunal Federal seria de } \\
\text { dezesseis ministros, alteração essa mantida pelo ato } \\
\text { institucional de 1967. No entanto, o ato institucional de } 1969 \\
\text { alterou a composição do STF reduzindo de dezesseis para } \\
\text { onze ministros. }\end{array}$ \\
\hline $\begin{array}{l}\text { Constituição da } \\
\text { República } \\
\text { Federativa do Brasil } \\
\text { de } 1988\end{array}$ & $\begin{array}{l}\text { Em } 5 \text { de outubro de } 1988 \text { o Estado democrático foi instituído } \\
\text { através da Constituição da República Federativa do Brasil, } \\
\text { assegurando direitos e deveres para a sociedade. A Carta } \\
\text { Magna estabeleceu que o Supremo Tribunal Federal é um } \\
\text { órgão do poder Judiciário, tendo sede na capital Federal, } \\
\text { jurisdição em todo território nacional, composto por onze } \\
\text { ministros, escolhidos pelo Presidente da República, } \\
\text { mediante aprovação por maioria absoluta do Senado }\end{array}$ \\
\hline
\end{tabular}


DOI 10.20873/uft.2359-0106.2021.v8n2.p293-323

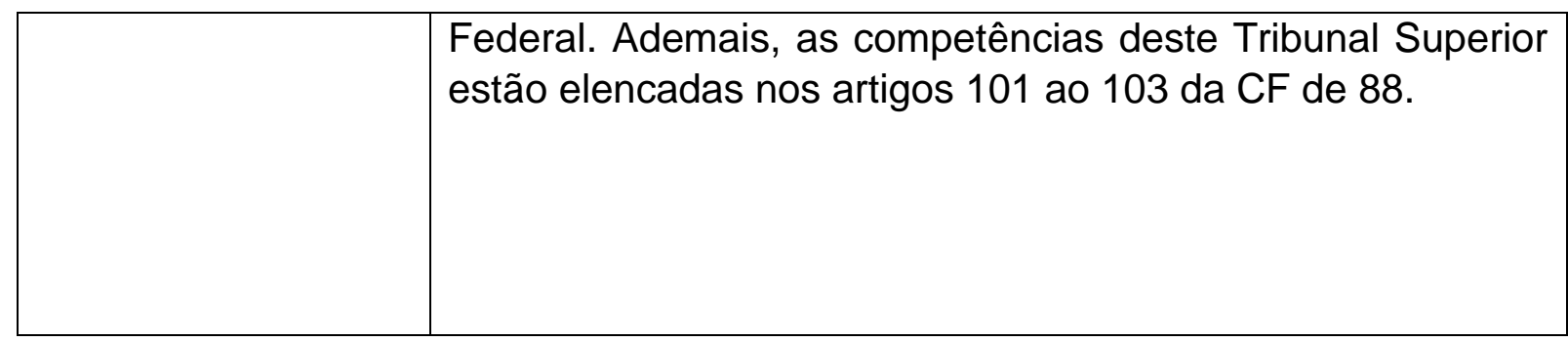

Fonte: Elaborado pela autora com base em BRASIL (1824, 1890, 1891, 1931, 1934, 1937, 1965, 1967, 1969, 1988, 2000c).

Diante das modificações demonstradas no quadro, pode-se perceber que, inicialmente, o Tribunal foi dotado de poderes, contudo, sofreu muitas modificações ao longo do tempo em relação a sua composição, suas atribuições e sua nomenclatura. Entretanto, o STF se fortaleceu bastante com o regime republicano, visto que durante o Estado Novo e no período após o Golpe Militar os governantes tentaram fazer com que o STF se curvasse aos interesses do poder Executivo (BRASIL, 2020c).

\subsection{Princípios constitucionais vinculados ao STF}

O Supremo Tribunal Federal é o guardião da lei suprema, isto é, o STF é responsável por assegurar que a Carta Magna não seja desrespeitada e que seus princípios sejam observados. Contudo, o STF não pode usar como argumentos as cláusulas pétreas para fundamentar decisões acerca da inconstitucionalidade em face das normas constitucionais, visto que a Constituição Federal as entende como limites ao poder constituinte derivado (BARROSO, 2019).

O STF deve observar e respeitar o princípio da separação dos poderes, visto que é um órgão que faz parte do poder Judiciário, ficando ele limitado à separação estabelecida pelo princípio. Contudo, os poderes não devem exercer suas funções de forma exclusiva, sendo assim, o STF tem a possibilidade de exercer as funções atípicas e, consequentemente, a prerrogativa de interferir nas funções do poder Legislativo (BRASIL, 2020e).

O princípio da insignificância também deve ser analisado pelo STF no momento de aplicar a sanção correta para cada caso, isto é, fica o STF responsável por analisar 
as condições necessárias para a aplicação desse princípio, sendo elas a mínima ofensividade da conduta, a ausência de periculosidade para a sociedade, amenizando o grau de reprovação da conduta e a falta da lesão provocada (BRASIL, 2020d). A ofensividade mínima faz referência ao bem jurídico tutelado, visto que deve ser justificável para não aplicar uma sanção, enquanto ao grau de reprovação ele deve ser estudado pelo STF para que analise a conduta, o motivo e as circunstâncias em que o agente estava imerso (CUCINELLI, 2015).

Não pode o STF justificar a não observância ao princípio da legalidade, visto que é um princípio norteador para as decisões coerentes, sob pena de nulidade da decisão. O Tribunal possui exemplos disso em sua jurisprudência, dado que o STF se negou a analisar o agravo de instrumento 887.644 em virtude de estar violando o princípio da legalidade. Diante disso, podemos observar que o STF afasta recurso extraordinário que viole a legislação (BRASIL, 2020b).

O princípio da moralidade administrativa é um dos princípios sobre os quais o STF se encontra vinculado, visto que seus acórdãos precisam se explicar e fundamentar na integração do caso concreto em questão. As regras que ordenam o princípio da moralidade podem vir a permitir o acórdão sem fundamentação, contudo, quando isso acontecer, será caracterizado como uma decisão nula, devendo ser tomada de ofício pelo juiz de acordo com o artigo 93, inciso IX da Carta Magna de 1988 (LOPES, 2017).

O Supremo Tribunal Federal está vinculado ao princípio da impessoalidade, isto é, o STF deve basear suas decisões distanciando suas opiniões individuais, não deve levar em consideração seu achismo ou fundamentar as decisões em seu interesse particular ou de terceiros. Deve embasar suas decisões no bem comum, atendendo as necessidades da coletividade. O princípio da impessoalidade deve ser usado para impedir decisões de cunho particular (CARVALHO, 2014).

\subsection{STF: entendimento e funções limitadas pela separação de poderes}


De acordo com o entendimento do ministro Celso de Mello do STF, não pode o Supremo Tribunal Federal usar das suas atribuições, em específica a Ação Direta de Inconstitucionalidade (ADI), para agir como um legislador positivo, visto que o poder de inovar é uma função típica da instituição parlamentar. Diante disso, fica o STF impossibilitado de inovar como legislador positivo, visto que entraria em conflito com o princípio da separação dos poderes (BRASIL, 1994).

Em conformidade com o ministro Celso de Mello, o ministro Dias Toffoli negou o pedido de parcelamento tributário diferenciado no Agravo de Instrumento 737.185, sob o argumento que o STF é impossibilitado de agir como um legislador positivo, preservando assim, sua função de legislador negativo nas possíveis declarações de inconstitucionalidades (BRASIL, 2012).

O Tribunal tem a competência para exercer a função de legislador, no entanto, só tem competência para criar uma norma destinada ao caso específico se houver ausência de uma norma positiva justa (KELSEN, 1999). Entretanto, o STF está imerso no dogma do legislador negativo, isto é, ele não deve ter uma atuação criativa, já que deve afastar as normas inconstitucionais, tornando-se assim um legislador em sentido negativo (CORREIA, 2015).

A ADI 896-0 não foi conhecida, visto que o entendimento da maioria dos ministros foi que a mesma não estava respeitando os limites do Tribunal e conhecer a ADI o obrigaria a atuar como legislador positivo, sendo que a Corte está restrita a examinar os dispositivos ou expressões cuja a inconstitucionalidade for arguida. A Corte é vedada de declarar a inconstitucionalidade parcial, isto é, a Corte tem que alcançar todo dispositivo, visto que se não atuar assim, pode estar agindo como um legislador positivo. Outro argumento utilizado na ADI 896-0 que teve como relator o ministro Moreira Alves, foi de que a Corte não pode suprimir expressões, dado que modificaria o seu sentido, com isto, foi negada a ADI por não atender as condições de ação direta de inconstitucionalidade (BRASIL, 1993).

O Supremo Tribunal Federal, em quase todos os momentos, está incumbido no dogma do legislador negativo estabelecido por Kelsen, costumando atuar em posição 
self-restraint quando se depara com situações em que é possível interpretar o texto ou numa decisão interpretativa modificativa, entretanto, nem sempre se atenta para os límites. O STF nem sempre toma o cuidado necessário para não ultrapassar as barreiras da interpretação dentro dos limites literais da lei e as interpretações modificativas dos textos originais, deixando assim, as discussões e estudos acesos para essas limitações do STF (BRASIL, 2006).

\subsection{Sentenças aditivas do STF}

O STF foi designado para ser o guardião da Carta Constitucional de 1988. Além disso, com a criação do recurso extraordinário ficou sob sua responsabilidade a revisão das decisões sobre a constitucionalidade de lei estadual e federal. Contudo, o STF tem inovado e demonstrado seu amplo poder, criando um rol extenso de jurisprudências que o coloca numa posição superior, pois abrange questões econômicas, sociais e políticas (MAIA, 2013).

O STF tem se comportado de forma mais ativa e isso pode estar gerando grandes conflitos com o sistema de freios e contrapesos, visto que sempre busca na legitimidade da proteção do texto constitucional o argumento para sanar as omissões deixadas pelos órgãos estatais responsáveis para realizá-las. À vista disso, essa forma mais ativa dos tribunais pode ser chamada de ativismo judicial (CAMPOS, 2011).

Segundo o Ministro Celso de Mello, o ativismo judicial consiste na necessidade transitória do poder Judiciário de suprir as omissões do poder Legislativo, principalmente em cumprir um dever constitucional específico de legislar ou executivo que podem causar prejuízos, visto que se o poder Legislativo deixa de criar as leis designadas pela Constituição há um problema sério de omissão legislativa, podendo assim afetar os outros poderes e a sociedade (BRASIL, 2020e).

As sentenças aditivas são ferramentas que buscam corrigir as omissões do poder Legislativo e são aplicadas nas decisões de acolhimento que não só julgam a inconstitucionalidade parcial de uma disposição normativa, mas que também reparam 
imediatamente a ausência ou lacuna criada pelo próprio componente que pode ser extraído da sentença, através da identificação aplicável (BRASIL, 2020f).

Segundo o STF, as sentenças aditivas são utilizadas quando falta algum requisito e, como consequência, desrespeita as regras, tornando-se então inconstitucional. Quando isto ocorre, denomina-se a inconstitucionalidade por omissão. Entretanto, além da inconstitucionalidade parcial, ela também pode ser total quando não existir na legislação uma norma sobre determinado caso, com isto, o poder Judiciário a modifica e complementa para que assim, se encaixe nos ditames legais (LESSA, 2018).

Entretanto, de acordo com o entendimento do ministro Joaquim Barbosa, as resoluções das sentenças aditivas surgem em contexto excepcional e transitório, exclusivamente como mecanismos para adotar medidas a observância da fidelidade partidária, enquanto o poder Legislativo, detentor dessa função típica, não se pronuncia, ficando então de maneira temporária a responsabilidade para o poder Judiciário de resolver a omissão do Legislativo (BRANDÃO, 2014).

Como regra, o cargo de legislar é do poder Legislativo, sendo ele o detentor da obrigação de criar ou não leis acerca de determinadas matérias, diante disso, sua decisão de não criar ou sua decisão política não necessita ser considerada inconstitucional. No entanto, se a Constituição determinar que o Legislativo deve agir e ele continuar inerte, sua decisão será considerada ilegítima e, com isto, inconstitucional por omissão (BARROSO, 2019).

\section{MINISTÉRIO PÚBLICO E A TEORIA DO QUARTO PODER}

A Constituição Federal de 1988, também chamada de Constituição Cidadã, ao dispor sobre a organização dos poderes, prevê em seu artigo $127^{3}$ O Ministério Público como uma instituição permanente, essencial à função jurisdicional do Estado, incumbindo-lhe a defesa da ordem jurídica, do regime democrático e dos interesses sociais e individuais indisponíveis (BRASIL, 1988).

\footnotetext{
3 “Art. 127. O Ministério Público é instituição permanente, essencial à função jurisdicional do Estado, incumbindo-lhe a defesa da ordem jurídica, do regime democrático e dos interesses sociais e individuais indisponíveis.” (BRASIL, 1988)
} 
A unidade, independência funcional e a indivisibilidade são princípios institucionais do MP. Segundo a Carta Magna, o MP tem autonomia funcional e administrativa, ao qual incumbe a viabilidade de sugestão ao Legislativo para criação ou extinção de cargos e serviços auxiliares. Além disso, os membros do MP são constituídos através de concurso público de provas ou de provas e títulos, a política remuneratória e os planos de carreira; a lei disporá sobre sua organização e funcionamento (BRASIL, 1988).

O Ministério Público é composto pelo MP da União que abrange o MP Federal, do Trabalho, Militar, do Distrito Federal e Territórios e os Ministérios Públicos dos estados (BRASIL, 1988). Os membros do MP fazem parte de um único órgão e isto é denominado de princípio da unidade. Ademais, segundo o princípio da indivisibilidade, os membros podem substituir uns aos outros, sem que acarrete prejuízos (ALMEIDA, 2010).

Em conformidade com a lei, o Ministério Público é um instituto independente, isto é, só deve obediência às leis, ninguém pode determinar o que o MP deve ou não fazer e, ainda que fizessem, ele teria a autonomia para atender ou não (ALMEIDA, 2010). O MP é independente, não deve obediência nem ao superior hierárquico, visto que age em nome da sociedade, de acordo com a Carta Magna e em prol da instituição (PASTORE, 2014).

Uma possibilidade da aplicação do princípio da independência do MP é o pedido de arquivamento do inquérito policial ou de quaisquer elementos informativos da mesma natureza, o órgão do MP comunicará à vítima, ao investigado e à autoridade policial e encaminhará os autos para a instância de revisão ministerial para fins de homologação, na forma da lei (BRASIL, 1941).

\subsection{Função jurisdicional do Ministério Público}

O Ministério Público tem justificado suas inovações e decisões com base no princípio da independência funcional que lhe foi assegurado pela Carta Magna de 1988. A evolução das funções do MP estão nítidas e estão causando mudanças na estrutura do ordenamento jurídico, obrigando assim, a criação de novos debates e 
aperfeiçoamentos por parte dos poderes fundamentais, visto que essa estrutura organizacional pode vir a ser atualizada (PASTORE, 2014).

É privativo do Ministério Público a propositura de ação penal pública, isto é, uma relação processual só pode ter início por meio de provocação da pessoa encarregada de deduzir a pretensão punitiva. Diante disso, fica o magistrado impossibilitado de tomar iniciativas que não se alinhem à vontade das partes, retirando assim os poderes de investigação por parte do juiz, visto que este deve ser uma figura imparcial (LIMA, 2019).

Ao MP foi conferido pela CF a função de promover de forma privativa a ação pública, sendo assim, o MP e o Judiciário são condiscípulos, já que o Ministério Público seria o deflagrador e o Judiciário finalizador. Além disso, a CF conferiu ao Ministério Público funções que funcionam em conjunto, as quais estão previstas no artigo 127 da Carta Magna de 1988 (RIBEIRO, 2011).

Além de ocasionar, exclusivamente, a ação penal pública, também é função do MP fiscalizar a execução da lei, o que faz nos crimes de ação penal pública, e também quando ocupa o polo ativo nas infrações penais de ação penal privada, em que sua interação também é obrigatória, fiscalizando a instauração e o desenvolvimento do processo, assim como o cumprimento da lei e da Constituição Federal (LIMA, 2019).

De acordo com as possibilidades do artigo 386 do Código de Processo Penal $(\mathrm{CPP})^{4}$, é possível que o Ministério Público pleiteie a absolvição do acusado. Seguindo essa linha, pode o Ministério público impetrar habeas corpus em favor da liberdade de locomoção do acusado, caso seja observado um constrangimento ilegal em decorrência da privação de liberdade (LIMA, 2019).

\subsection{A teoria do poder de investigação do Ministério Público}

\footnotetext{
4 "Art. 386. O juiz absolverá o réu, mencionando a causa na parte dispositiva, desde que reconheça: I estar provada a inexistência do fato; II - não haver prova da existência do fato; III - não constituir o fato infração penal; IV - estar provado que o réu não concorreu para a infração penal; $V$ - não existir prova de ter o réu concorrido para a infração penal; $\mathrm{VI}$ - existirem circunstâncias que excluam o crime ou isentem o réu de pena (arts. 20,21, 22, 23, 26 e $\S 1^{\circ}$ do art. 28, todos do Código Penal), ou mesmo se houver fundada dúvida sobre sua existência; (Redação dada pela Lei no 11.690 , de 2008); VII - não existir prova suficiente para a condenação." (BRASIL, 1941)
} 
A Carta Magna de 1988 designou ao MP a função de defender a ordem jurídica, o regime democrático e os interesses sociais e individuais (art. 127, caput) (BRASIL, 1988). Entretanto, dentre as funções elencadas no artigo 129 e seus incisos, não está expressa a possibilidade de o MP exercer função de investigação criminal, visto que a função de investigação criminal é de competência da polícia judiciária (BRASIL, 1988).

Em 2011 foi proposta uma emenda (PEC 37/2011) à Carta Magna de 1988 para definir como competência das polícias federais, policiais civis dos estados e Distrito Federal para investigação criminal. Contudo, a PEC 37/2011 foi rejeitada em 2013 pelo plenário do Tribunal. Diante disso, os debates, estudos e reflexões a respeito da competência do Ministério Público continuam acesos (BRASIL, 2011).

Além disso, o entendimento do STF ficou nítido através de uma repercussão geral (RE 593.727/MG) ao qual demonstra que o MP tem a competência para promover, por autoridade própria investigação criminal, visto que a constituinte não destinou com exclusividade a função de investigação criminal para a polícia judiciária. Entretanto, o Ministério Público deve respeitar os direitos e deveres garantidos aos indiciados (BRASIL, 2015).

Contudo, existem doutrinadores que entendem que o MP não tem competência para investigação criminal e se assentam nos seguintes argumentos: a investigação pelo MP causa um desequilíbrio no sistema acusatório, as funções designadas ao MP pela CF de 1998 foram de instaurar inquéritos policiais e diligências (art. 129, VIII) e a função de investigação criminal seria exclusivamente da polícia judiciária (LIMA, 2019).

Em contrapartida, alguns doutrinadores defendem a competência do MP para investigação criminal alicerçando-se em argumentos como a inexistência de violação do sistema acusatório, visto que os elementos colhidos pelo MP possuem o mesmo tratamento que os elementos colhidos pela polícia judiciária. Outro argumento que os doutrinadores se basearam foi a teoria dos poderes implícitos que dispõe que se um órgão inicia a função, ele deve terminá-la. Diante desse entendimento, o MP sendo 
encarregado da última palavra na ação penal pública (art. 129, inciso I, CF) sobre sua responsabilidade também a investigação penal para que dessa forma consiga firmar seu posicionamento (LIMA, 2019).

\subsection{A suposta usurpação da função típica da polícia judiciária por parte do Ministério Público}

O artigo $5^{\circ}$ da Lei Suprema de $1988^{6}$ dispõe que é dever do Estado garantir a segurança dos indivíduos e respeitar seus direitos. Entretanto, o Estado pode a vir restringi-los em prol do bem da coletividade e, para tanto, pode vir a utilizar os seus poderes de polícia, visando o princípio da supremacia do interesse público que sobrepõe o particular. O Estado instituiu um órgão policial para assegurar e manter a ordem pública (SILVA, 2006).

O Promotor de Justiça ou Procurador da República tem conhecimento dos parâmetros que irão basear a decisão de acusar ou requerer o arquivamento do inquérito de investigações criminais ou, até mesmo, de requerer ou não das sentenças (PRADO, 2005). O parágrafo único do artigo 4ํ do Código de Processo Penal ${ }^{7}$ revoga a exclusividade da polícia judiciária para apuração das infrações penais e de sua autoria (BRASIL, 1941).

A polícia judiciária é responsável por apurar a infração penal e sua autoria, frequentemente invade a camada da privacidade dos indivíduos, de forma legal para que possa analisar a reputação da pessoa suspeita. Diante dessas responsabilidades dadas à polícia judiciária, as fronteiras entre o permitido e proibido ficam próximas e, para resguardar a legalidade da investigação, o Ministério Público fica encarregado de fiscalizar os atos da investigação (PRADO, 2005).

\footnotetext{
5 "Art. 129. São funções institucionais do Ministério Público: I - promover, privativamente, a ação penal pública, na forma da lei;" (BRASIL, 1988)

6 "Art. 5ำ Todos são iguais perante a lei, sem distinção de qualquer natureza, garantindo-se aos brasileiros e aos estrangeiros residentes no País a inviolabilidade do direito à vida, à liberdade, à igualdade, à segurança e à propriedade, nos termos seguintes:" (BRASIL, 1988)

7 "Art. 4ํㅡ A polícia judiciária será exercida pelas autoridades policiais no território de suas respectivas circunscrições e terá de pôr fim à apuração das infrações penais e da sua autoria. Parágrafo único. A competência definida neste artigo não excluirá a de autoridades administrativas, a quem por lei seja cometida a mesma função." (BRASIL, 1941)
} 
É de responsabilidade da polícia judiciária a realização da investigação criminal para que possa sanar se existe ou não a prática de um determinado crime e analisar quem foi o autor e, dessa forma, o órgão responsável pela acusação vai poder atuar (NUNES, 2014). Contudo, de acordo com o artigo 129, inciso I da Carta Magna de 1988 o Ministério é responsável por dar início a ação penal pública. Além disso, o inciso VII deste mesmo artigo dispõe que o MP é responsável por fiscalizar as atividades externas da polícia (BRASIL, 1988).

Existe a possibilidade de o MP investigar de forma direta, contudo essa possibilidade depende de autorização legal, isto é, necessita de previsão legal. Entretanto, essa forma de investigação do MP é excepcional e só é justificável em virtude da identidade do investigado, ou melhor, quando a investigação é em decorrência da corrupção de um policial ou a crimes na própria polícia (PRADO, 2005).

Ao MP foi garantido pela Carta Magna de 1988 o direito de exigir que a investigação seja feita, visto que tem o direito de requisição. Toda vez que a polícia judiciária negligenciar uma investigação, isto é, que não apure os acontecimentos, o MP pode exigir que a investigação seja realizada e dessa forma irá sanar a negligência da polícia. Diante disso, pode-se perceber que o legislador tinha como finalidade que a polícia judiciária e o MP atuassem em conjunto e um cooperando com a necessidade do outro para assegurar o direito de investigação e, consequentemente, o procedimento mais célere (NUNES, 2014).

\section{DA (IM)POSSIBILIDADE DO FIM DA TEORIA TRIPARTITE}

A teoria tripartite surgiu para limitar que os poderes sejam exercidos por um único indivíduo ou um órgão e, em virtude disso, as funções devem ser exercidas por órgãos distintos para que dessa forma não aconteça a usurpação de poderes. Faz-se necessária a independência orgânica, isto é, não pode haver subordinação e dependência dos poderes e, para tanto, a Lei Suprema de 1988 instituiu um mecanismo específico, estabelecendo assim, o sistema de freios e contrapesos para garantir a harmonia entre os poderes (CUNHA JÚNIOR, 2012). 
Os Estados jurídicos, de um jeito ou de outro, faziam menções à divisão de poderes ou separação dos poderes e, de acordo com os estudos teóricos anteriores, a divisão de funções. Entretanto, não há de se falar de divisão de poderes, visto que o que foi dividido foram as funções e destinadas aos órgãos. Nesse sentido, não existe soberania entre as funções, visto que a Constituição atribuiu o grau máximo de poder ao povo (MACHADO, 2006).

Um dos poderes da separação é o Judiciário, sendo ele responsável pela proteção jurisdicional, desempenhando um papel importante, visto que faz o controle dos abusos dos atos omissos ou comícios dos outros poderes. Ao poder Judiciário foi designada a função de guardião da Constituição, entretanto, ele vem inovando e a sua capacidade de criar o Direito tem se mostrado incontestável. Entretanto, o poder Judiciário tem suas funções limitadas em decorrência da separação tripartite, visto que ela surgiu para que os poderes sejam harmônicos entre si (CUNHA JÚNIOR, 2012).

O poder Judiciário não pode criar normas para não usurpar a função típica do poder Legislativo, contudo, o Ministério Público que antes era um órgão parte do poder Executivo, no momento é um órgão independente dos demais poderes. A ausência de vínculo com outros poderes é uma forma de perceber a independência do MP por parte dos demais poderes (CÔRTES, 2010).

O MP é um órgão independente, não deve se subordinar a outro poder, tendo ele a possibilidade de propor criação ou extinção de cargos ao Legislativo, podendo também praticar atos próprios da gestão, elaborar folhas de pagamento, organizar suas secretarias, elaborar seus regimentos internos. Mesmo diante de um leque de atribuições destinadas ao MP, não há de se falar na expressão de quarto poder, visto que o poder é um só e o detentor dele é o Estado, somente as funções são divididas (TIMBÓ, 2007).

Independência da separação dos poderes significa dizer que uma pessoa pode fazer parte de um poder, sem a anuência dos demais poderes, que não precisam de autorização para exercer suas funções, que os poderes são livres, devendo observar 
apenas a Constituição. A interferência pelo sistema de freios contrapesos objetiva que os poderes atuem reciprocamente, isto é, em sintonia e harmonia (SILVA, 2005).

A separação é harmônica, visto que o Legislativo cria, mas necessita do veto ou sanção do poder Executivo. Enquanto aos Tribunais, se não podem inferir no Legislativo, é sua atribuição declarar a inconstitucionalidade das leis e, neste caso, não são aplicadas. Diante disso, observa-se que os poderes são regidos pelo princípio da separação ou harmonia e isto não significa que pode ocorrer usurpação de funções, mas sim que deve ocorrer controle e colaborações recíprocas (SILVA, 2005).

O STF não tem suas funções limitadas pela tripartição, dado que cada poder tem uma função e ele pode de forma atípica legislar. Nesse sentido, pode o Legislativo administrar e julgar, mesmo que de forma atípica. A finalidade de cada poder é atuar para o bem comum da sociedade, sendo assim, o MP também se iguala aos demais poderes, visto que tem como finalidade o bem estar social (TIMBÓ, 2007).

A Constituição de 1988 instituiu os três poderes, ela organizou, designou deveres e atribuições, buscou equilibrar o poder de cada um para que não ocorra agigantamentos ou depreciações de um para com outra esfera de poder. A Lei Maior, quando constituiu cada um, se debruçou para que os direitos, as garantias e os princípios fossem respeitados e, para tanto, estabeleceu a separação de poderes como uma cláusula pétrea (ARAÚJO, 2007). As cláusulas pétreas são dispositivos invioláveis da Constituição Federal de 88, não podem ser alterados nem mesmo com proposta de emenda à CF (BRASIL, 2020a). Ademais, pode-se observar que não pode ocorrer subtração ou adição de poderes sob pena de violação da cláusula pétrea da separação dos poderes.

\section{CONSIDERAÇÕES FINAIS}

O Supremo Tribunal Federal é um dos órgãos da tripartição de poderes e, de acordo com o entendimento de alguns doutrinadores, têm suas funções limitadas em decorrência da separação estabelecida pela Constituição Federal. Contudo, a 
possibilidade da existência de um novo poder iria fundamentar o possível fim da teoria tripartite.

Diante do tratado nos tópicos anteriores, percebe-se que o Ministério Público é um órgão independente e, consequentemente, ultrapassa os limites impostos pela CF, mas não seria o caso de afirmar a existência de um novo poder e sim de procurar formas para que o MP faça apenas o que the foi ordenado, visto que a possibilidade da existência de um quarto poder é vedada pela própria CF de 1988.

Entretanto, não seria o caso de afirmar a existência de um quarto poder e sim de limitar o poder do Ministério Público, cabendo ao STF, poder legislativo ou até mesmo o executivo fazer essa limitação, visto que, trata-se da possibilidade da existência de um novo poder, é em virtude de que na prática as coisas não saírem tão perfeitas como na teoria. Deve-se questionar o porquê do MP seguir inovando e fundamentando essa inovação através do princípio da independência funcional. Diante disso, deve-se questionar também até onde vai essa independência do MP.

A CF de 1998 garante ao MP o direito de promover o início da ação penal pública, e de ocupar o polo ativo nas infrações penais de ação penal privada, em que sua interação também é obrigatória, fiscalizando a instauração e o desenvolvimento do processo, assim como o cumprimento da lei e da Constituição Federal. Mas em nenhum momento a CF de 1998 faz menção de que pode o MP fazer o papel da polícia judiciária. O que é conferido ao MP? É o de dar início à ação penal pública, mas quem tem o poder de investigação criminal é a polícia judiciária. Só cabe ao MP investigar de forma direta, se for autorizado legalmente, isto é, necessita de previsão legal. Entretanto, essa forma de investigação do MP é excepcional e só é justificável em virtude da identidade do investigado, ou melhor, quando a investigação é em decorrência da corrupção de um policial ou a crimes na própria polícia.

Destarte, não cabe ao STF decidir se pode ou não criar leis, mesmo sendo uma modalidade permitida de forma atípica, apenas sendo possível de forma justificada. Ademais, falar em um quarto poder para justificar o fim da tripartição de poderes é o 
mesmo que rasgar a Constituição Federal de 1988, visto que é inconstitucional e a única forma para se fazer isso é constituir uma nova Lei Maior.

O SFT, ele deve ter suas funções limitadas sim, pois deve-se lembrar o motivo pelo qual existe a separação dos poderes, isto é, é uma forma para preservar a democracia, porque se pegar todos os poderes e concentrar nas mãos de uma única pessoa, ainda há de se falar em democracia? Um poder que cria, que executa e que julga, não seria satisfatório para todos.

O primeiro capítulo tratou sobre a separação dos poderes e da teoria tripartite, demonstrando a importância do indivíduo para o ordenamento jurídico e a continuação do Estado de Direito, analisando como a separação e a teoria foram estabelecidas através do sistema de freios e contrapesos e o porquê de sua criação, visto que a CF a reconheceu como um princípio constitucional e, para assegurar sua observância, a transformou em cláusula pétrea, impedindo assim, sua alteração ou abolição.

O segundo capítulo demonstrou a evolução do STF, visto que é um dos órgãos do poder Judiciário e analisou suas atribuições para verificar se existe uma limitação de suas funções e, para tanto, foi utilizado o seu entendimento através de suas sentenças. Neste sentido, o STF tem demonstrado respeito ao princípio da separação dos poderes e aos demais princípios constitucionais, isto é, ele está atuando como um legislador negativo e em prol da harmonia dos poderes.

Já o terceiro capítulo se debruçou na atuação do Ministério Público para que, dessa maneira, demonstre se o MP consiste ou não em um novo poder. Contudo, podese perceber, diante do que foi apresentado, que o MP está atuando dentro dos limites estabelecidos pela Constituição de 1988. Ao MP foi atribuída a possibilidade de atuar na investigação criminal através do início da ação penal pública e, em virtude disso, não há de se falar de usurpação de poder da polícia judiciária.

Por fim, o quarto capítulo versou sobre a (im)possibilidade do fim da teoria tripartite, sendo que foi demonstrada a impossibilidade dessa extinção em virtude da Constituição de 1988. Neste contexto, para se alegar o fim da teoria se faria necessária uma nova Constituição, visto que a atual Carta Magna proíbe essa possibilidade 
através da cláusula pétrea firmada pela separação dos poderes. Diante do exposto, o fundamento para que a teoria do quarto poder seja infundada é a inconstitucionalidade da possibilidade da alteração do princípio da separação e, em virtude disso, não se pode alterar as funções atribuídas aos poderes, não cabendo ao STF contestar isso.

Diante disso, é importante demonstrar a necessidade da pesquisa para minimizar os impactos causados ao Judiciário, posto que corrobora para a ascensão das funções do STF, buscando facilitar o desenvolvimento das funções típicas e atípicas da separação dos poderes. Esse estudo abre a possibilidade de modificações no entendimento atual e, dessa forma, uma nova visão do mundo jurídico e acadêmico deve surgir.

Por conseguinte, é relevante articular sobre a possibilidade da existência de um novo poder, uma vez que enfraqueceria uma teoria que por muitos anos se entendeu como coerente. Diante disso, vale a pena articular acerca de um novo poder, visto que o ordenamento jurídico sempre se renova. Porém, em decorrência da pandemia do Covid19, a investigação restou limitada aos livros e artigos disponibilizados na internet ou bibliotecas digitais, impedindo, por exemplo, a pesquisa de campo, sendo essa opção uma forma enriquecedora, visto que existiria a possibilidade de dialogar com os servidores que vivenciam essas teorias.

\section{REFERÊNCIAS}

ALMEIDA, Fernanda Leão de. A garantia institucional do Ministério Público em função da proteção dos Direitos Humanos. Tese (Doutorado em Direito) - Faculdade de Direito, Universidade de São Paulo, São Paulo, 2010.

ARAÚJO, Rosa Maria Felipe. $O$ princípio da separação de poderes e a competência normativa do Tribunal Superior Eleitoral. Dissertação (Mestrado em Direito Constitucional) - Fundação Edson Queiroz, Universidade de Fortaleza, Fortaleza, 2007. ARISTÓTELES. Política. São Paulo: Martin Claret, 1991.

Ato Institucional no 2, de 27 de outubro de 1965. Mantém a Constituição Federal de 1946, as Constituições Estaduais e respectivas Emendas, com as alterações introduzidas pelo Poder Constituinte originário da Revolução de 31.03.1964, e dá outras providências. Brasília: Presidência da República, 
1965. Disponível em: http://www.planalto.gov.br/ccivil_03/ait/ait-02-65.htm. Acesso em: 22 nov. 2020.

Ato Institucional no 5, de 13 de dezembro de 1968. São mantidas a Constituição de 24 de janeiro de 1967 e as Constituições Estaduais; O Presidente da República poderá decretar a intervenção nos estados e municípios, sem as limitações previstas na Constituição, suspender os direitos políticos de quaisquer cidadãos pelo prazo de 10 anos e cassar mandatos eletivos federais, estaduais e municipais, e dá outras providências. Brasília: Presidência da República, 1968. Disponível em: http://www.planalto.gov.br/ccivil_03/ait/ait-05-68.htm. Acesso em: 22 nov. 2020.

Ato Institucional no 6, de 1 ㅇ de fevereiro de 1969. Altera a composição e competência do Supremo Tribunal Federal, amplia a disposição do Ato Institucional $\mathrm{n}^{\circ}$ 5, de 13 de dezembro de 1968 e ratifica as emendas constitucionais feitas por Atos Complementares. Brasília: Presidência da República, 1969. Disponível em: http://www.planalto.gov.br/ccivil_03/ait/ait-06-69.htm. Acesso em: 22 nov. 2020.

BADAWI, Karina Bonetti. Separação dos poderes no Brasil e a teoria de Bruce Ackerman. Tese (Doutorado em Direito Político e Econômico) - Universidade Presbiteriana Mackenzie, São Paulo, 2014.

BARBOSA, Ademar Cypriano. Divisão de poderes e jurisdição constitucional direta: ressignificação do princípio e precisão conceitual da função no sistema brasileiro. Dissertação (Mestrado em Direito, Estado e Constituição) - Faculdade de Direito, Universidade de Brasília, Brasília, 2016.

BARROSO, Luís Roberto. Curso de Direito Constitucional contemporâneo: os conceitos fundamentais e a construção do novo modelo. São Paulo: Saraiva, 2019.

BONAVIDES, Paulo. Ciência Política. São Paulo: Malheiros Editores, 2016.

BRANDÃO, Rodrigo. O STF e o Dogma do Legislador Negativo. Revista Direito, Estado e Sociedade, Rio de Janeiro, n. 44, p. 189-2020, 2014.

BRASIL. Constituição Política do Império do Brazil de 1824. Rio de Janeiro, Império do Brasil, $1824 . \quad$ Disponível em: http://www.planalto.gov.br/ccivil_03/Constituicao/Constituicao24.htm. Acesso em: 04 de set. 2020

Constituição da República dos Estados Unidos do Brasil de 1891. Rio de Janeiro: Presidência da República, 1891. Disponível em: http://www.planalto.gov.br/ccivil_03/constituicao/constituicao91.htm. Acesso em: 22 nov. 2020. 
. Constituição da República dos Estados Unidos do Brasil de 1934. Rio de Janeiro: Presidência da República, 1934. Disponível em: http://www.planalto.gov.br/ccivil_03/constituicao/constituicao34.htm. Acesso em: 22 nov. 2020.

Constituição da República dos Estados Unidos do Brasil de 1937. Rio de Janeiro: Presidência da República, 1937. Disponível em: http://www.planalto.gov.br/ccivil_03/constituicao/constituicao37.htm. Acesso em: 22 nov. 2020.

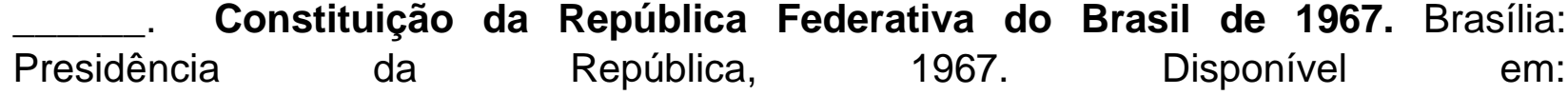
http://www.planalto.gov.br/ccivil_03/constituicao/constituicao67.htm. Acesso em: 22 nov. 2020.

. Constituição da República Federativa do Brasil de 1988. Brasília: Presidência da República, 1988. Disponível em: http://www.planalto.gov.br/ccivil_03/constituicao/constituicao.htm. Acesso em: 22 nov. 2020

. Proposta de emenda à Constituição no 37/2011. Acrescenta o $\S 10$ ao art. 144 da Constituição Federal para definir a competência para a investigação criminal pelas polícias federal e civis dos Estados e do Distrito Federal. Brasília: Câmara dos Deputados, $2011 . \quad$ Disponível em: https://www.camara.leg.br/proposicoesWeb/fichadetramitacao?idProposicao=507965. Acesso em: 04 set. 2020

.Decreto-Lei no 3.869, de 03 de outubro de 1941. Código de Processo Penal. Rio de Janeiro: Presidência da República, 1941. Disponível em: http://www.planalto.gov.br/ccivil_03/decreto-lei/del3689compilado.htm. Acesso em: 15 set. 2020.

Senado Federal. Decreto no 19.656, de 3 de fevereiro de 1931. Reorganiza provisoriamente o Supremo Tribunal Federal e estabelece regras para abreviar os seus julgamentos. Rio de Janeiro: Presidência da República, 1931. Disponível em: https://legis.senado.leg.br/norma/437446/publicacao/15694129. Acesso em: 04 set. 2020.

.Senado Federal. Decreto no 510, de 22 de junho de 1890. Pública a Constituição dos Estados Unidos do Brazil. Rio de Janeiro: Império do Brasil, 1890. Disponível em: http://legis.senado.leg.br/norma/388004/publicacao/15722625. Acesso em: 04 set. 2020.

.Supremo Tribunal Federal. Ação Direta de Inconstitucionalidade - Distrito Federal. Relator: Min. Celso de Mello, 18 de maio de 1994. Disponível em: 
http://redir.stf.jus.br/paginadorpub/paginador.jsp?docTP=AC\&doclD=346801. Acesso em: 04 set. 2020.

.Supremo Tribunal Federal. Ação Direta de Inconstitucionalidade 1.351-3 Distrito Federal. Relator: Min. Marco Aurélio, 07 de dezembro de 2006. Disponível em: http://redir.stf.jus.br/paginadorpub/paginador.jsp?docTP=AC\&doclD=414316. Acesso em: 04 set. 2020.

.Supremo Tribunal Federal. Ação Direta de Inconstitucionalidade 5468. Relator: Min. Luiz Fux, 30 de junho de 2016. Disponível em: http://www.stf.jus.br/portal/jurisprudencia/menuSumarioTese. asp?tipo=TCC\&tese=4631 . Acesso em: 15 set. 2020.

.Supremo Tribunal Federal. Ação Direta de Inconstitucionalidade 896-0 Distrito Federal. Relator: Min. Moreira Alves, 03 de novembro de 1993. Disponível em: http://redir.stf.jus.br/paginadorpub/paginador.jsp?docTP=AC\&doclD=346676. Acesso em: 04 set. 2020.

.Supremo Tribunal Federal. Agravo de Instrumento 737.185. Relator: Min. Dias Toffoli, 19 de setembro de 2012. Disponível em: http://portal.stf.jus.br/processos/downloadPeca. asp?id=99275062\&ext=.pdf. Acesso em: 04 set. 2020.

.Supremo Tribunal Federal. Aplicação das Súmulas no STF. Disponível em: http://www.stf.jus.br/portal/jurisprudencia/menuSumarioSumulas.asp?sumula=2836\#: :t ext=Viola\%C3\%A7\%C3\%A30\%20a0\%20princ\%C3\%ADpio\%20da\%20legalidade,sentid 0\%20\%C3\%A0\%20luz\%20da\%20Constitui\%C3\%A7\%C3\%A3o. Acesso em: 15 set. $2020 \mathrm{~b}$.

Supremo Tribunal Federal. Histórico. Disponível em: http://www.stf.jus.br/portal/cms/verTexto.asp?servico=sobreStfConhecaStfHistorico. Acesso em: 04 set. 2020c.

\begin{tabular}{llll}
\multicolumn{4}{c}{ Supremo Tribunal Federal. Princípio da insignificância é aplicado a furto de } \\
objetos & de pouco & valor.
\end{tabular} http://www.stf.jus.br/portal/cms/verNoticiaDetalhe.asp?idConteudo=173584\#: :text=0\% 20 princ\%C3\%ADpio\%20da\%20insignific\%C3\%A2ncia\%20\%C3\%A9,a\%20inexpressivid ade\%20da\%20les\%C3\%A3o\%20provocada. Acesso em: 15 set. 2020d.

.Supremo Tribunal Federal. Recurso Extraordinário 593.727 - MG. Relator: Min. Cezar Peluso, 14 de maio de 2015. Disponível em: http://redir.stf.jus.br/paginadorpub/paginador.jsp?docTP=TP\&doclD=9336233. Acesso em: 22 nov. 2020.

.Supremo Tribunal Federal. Suprema Corte brasileira e o exercício de suas atribuições constitucionais. 
http://www.stf.jus.br/portal/cms/verNoticiaDetalhe.asp?idConteudo=165752. Acesso em: 24 ago. 2020e.

Supremo Tribunal Federal. Vocábulo Jurídico (Tesauro). Sentença aditiva. http://www.stf.jus.br/portal/jurisprudencia/listarTesauro.asp?txtPesquisaLivre=SENTEN \%C3\%87A\%20ADITIVA. Acesso em: 24 ago. $2020 f$.

CAMARGO, Beatriz Meneghel Chagas. A separação dos poderes e os freios e contrapesos na Constituição de 1988: a atuação do Poder Judiciário. Dissertação (Mestrado em Direito Constitucional) - Pontifícia Universidade Católica de São Paulo, São Paulo, 2017.

CAMPOS, Carlos Alexandre de Azevedo. Atualidades do Controle Judicial da Omissão Legislativa Institucional. Revista Direito Público, Brasília, n. 42, p. 47-83, 2011.

CANOTILHO, José Joaquim Gomes. Direito Constitucional e teoria da constituição. 7. ed. Coimbra: Almedina, 2003.

CARVALHO, Paulo de Tarso Bilard de. O conceito jurídico do princípio de impessoalidade no Direito Administrativo brasileiro: uma releitura. Dissertação (Mestrado em Direito) - Faculdade de Direito, Universidade de São Paulo, São Paulo, 2014.

CORREIA, Clint Rodrigues. Sentenças aditivas e a superação do paradigma de legislador negativo. Dissertação (Mestrado em Direito Constitucional) - Pontifícia Universidade de São Paulo, São Paulo, 2015.

CÔRTES, Lara Barbosa Quadros. O Ministério Público e a defesa do direito à educação: um estudo de caso sobre a atuação dos promotores de justiça da grande São Paulo. Dissertação (Mestrado em Direito e Desenvolvimento) - Escola de Direito de São Paulo, Fundação Getúlio Vargas, São Paulo, 2010.

COSTA, Luciana da Silva. A revisitação do princípio da separação de poderes: dialogicidade e tensão como elementos conformadores da identidade constitucional brasileira. Tese (Doutorado em Direito) - Faculdade de Direito, Universidade de São Paulo, São Paulo, 2014.

CUCINELLI, Otavio Henrique Simão E. Da aplicação do princípio da insignificância aos atos de improbidade administrativa. Dissertação (Mestrado em Direito) Faculdade de São Paulo, Universidade de São Paulo, São Paulo, 2015.

CUNHA JÚNIOR, Dirley da. Curso de Direito Constitucional. Salvador: JusPodivm, 2012.

FERNANDES, Bernardo Gonçalves. Curso de Direito Constitucional. Rio de Janeiro: Lumen Juris, 2011. 
KELSEN, Hans. Teoria Pura do Direito. São Paulo: Martins Fontes, 1999.

LESSA, Alex Alves. Benefícios incompatíveis com o princípio da isonomia e as decisões intermediárias à disposição do Supremo Tribunal Federal. Dissertação (Mestrado em Direito Constitucional) - Escola de Direito de Brasília, Instituto Brasiliense de Direito Público, Brasília, 2018.

LIMA, Renato Brasileiro de. Manual de Processo Penal. Salvador: JusPodivm, 2019.

LOPES, Camila Laurentino. A moralidade administrativa no contexto democrático brasileiro: desencontros da doutrina administrativa e a jurisprudência do STF. Dissertação (Mestrado em Direito) - Faculdade de Direito de Recife, Universidade Federal de Pernambuco, Recife, 2017.

MACHADO, Ednilson Donisete. Decisão judicial sobre políticas públicas: limites institucionais democráticos e constitucionais. Tese (Doutorado em Direito) - Pontifícia Universidade Católica de São Paulo, São Paulo, 2006.

MAIA, Cristiano Soares Barroso. A sentença aditiva e o Supremo Tribunal Federal: entre o Estado de Direito e soberania popular. Dissertação (Mestrado em Direito, Constituição e Justiça) - Universidade de Brasília, Faculdade de Direito, Brasília, 2013.

MONTESQUIEU, Charles Louis de. O espirito das leis. São Paulo: Martins Fontes, 2000.

NASCIMENTO, Ricardo de Castro. Divisão de poderes: origem, desenvolvimento e atualidades. Tese (Doutorado em Direito Constitucional) - Pontifícia Universidade Católica de São Paulo, São Paulo, 2017.

NUNES, André Dias. A Investigação Criminal Brasileira: a crise entre a polícia judiciária e o Ministério Público. Dissertação (Mestrado em Direito) - Pontifícia Universidade Católica do Rio de Janeiro, Rio de Janeiro, 2014.

PASTORE, Délton Esteves. O Ministério Público na ordem constitucional brasileira e sua atuação no processo civil. Tese (Doutorado em Direito) - Faculdade de Direito, Universidade de São Paulo, São Paulo, 2014.

PRADO, Geraldo. Sistema acusatório: a conformidade Constitucional das leis processuais penais. Rio de Janeiro: Lumen Juris, 2005.

RIBEIRO, Carlos Vinícius Alves. As funções extrajudiciais do Ministério Público: natureza jurídica, discricionariedade e limites. Dissertação (Mestrado em Direito do Estado) - Faculdade de Direito, Universidade de São Paulo, São Paulo, 2011.

SILVA, José Afonso da. Curso de Direito Constitucional Positivo. São Paulo: Malheiros Editores, 2005. 
SILVA, Marcio Cesar Fontes. A investigação criminal, a polícia judiciária e o Ministério Público. Dissertação (Mestrado em Direito Processual Penal) - Pontifícia Universidade Católica de São Paulo, São Paulo, 2006.

STRECK, Lenio Luiz. Jurisdição Constitucional. Rio de Janeiro: Forense, 2018.

Senado Federal. Cláusula Pétrea. Disponível em: https://www12.senado.leg.br/noticias/glossario-legislativo/clausula-petrea. Acesso em: 22 set. 2020 a.

TIMBÓ, Wander de Almeida. O Ministério Público como poder do Estado. Monografia (Especialização em Direito Constitucional e Direito Processual Constitucional) - Centro de Estudos Sociais Aplicados, Universidade Federal do Ceará, Fortaleza, 2007. 